\title{
Regerach автісі: Growth and yield response of lowland rice to different application methods of zinc with green leaf manuring
}

\author{
P. PRAKASH, M. HEMALATHA, A. VELAYUTHAM, R. AMUTHA AND \\ M. JOSEPH
}

Article Chronicle: Received :

11.07.2017;

Accepted :

24.07.2017

KEY WoRDS:

Rice, Zinc, Green leaf manure, Growth, Yield

Author for correspondence :

\section{P. PRAKASH}

Agricultural College and

Research Institute

(T.N.A.U.), MADURAI (T.N.)

INDIA

See end of the article for authors' affiliations
SUMMARY : A field experiment was conducted to study the response of rice to different methods of zinc application with incorporation of green leaf manure at Agricultural College and Research Institute, Killikulam, TNAU, Tamil Nadu, during late Pishanam season (November - March) of 2015 - 2016. The field experiment was laid out in Randomized Block Design with three replication using rice ADT (R) 45 as a test variety. The treatment consists of twelve treatments, control (RDF alone), two method of application (as basal and foliar spray) of zinc with / without incorporation of green leaf manure Glyricidia maculata. Application of $\mathrm{ZnSO}_{4}$ as basal @ 12.5, 25 and $37.5 \mathrm{~kg} / \mathrm{ha}$ and foliar spray was given at two different levels 0.5 and 1 per cent at tillering and at panicle initiation stage, respectively. The recommended dose of NPK (150:50:50) was applied to all the treatment plots. There are significant difference was noticed in the growth parameters and yield of rice. The growth parameters (plant height, number of tillers, dry matter production), growth analysis (leaf area index and crop growth rate) and yield (grain and straw) were recorded. Among the different treatments, the higher growth parameters was recorded with application of 100\% RDF + GLM @ $6.25 \mathrm{t} / \mathrm{ha}+\mathrm{ZnSO}_{4} @ 12.5 \mathrm{~kg} / \mathrm{ha}$ as basal + Foliar spray of $\mathrm{ZnSO}_{4} @ 1.0 \%\left(\mathrm{~T}_{12}\right)$. Maximum grain and straw yield was achieved in the same treatment. The lowest growth parameters and yield (grain and straw) was noticed in the control plot.

How to cite this article : Prakash, P., Hemalatha, M., Velayutham, A., Amutha, R. and Joseph, M. (2017). Growth and yield response of lowland rice to different application methods of zinc with green leaf manuring. Agric. Update, 12(TECHSEAR-2) : 403-408; DOI: 10.15740/HAS/AU/12.TECHSEAR(2)2017/403-408. 